\title{
Horizon scanning for invasive alien species with the potential to threaten biodiversity and human health on a Mediterranean island
}

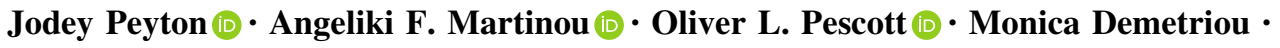 \\ Tim Adriaens - Margarita Arianoutsou - Ioannis Bazos - Colin W. Bean • \\ Olaf Booy - Marc Botham • J. Robert Britton · Javier Lobon Cervia • \\ Pantelis Charilaou • Niki Chartosia • Hannah J. Dean · Pinelopi Delipetrou • \\ Andreas C. Dimitriou • Gerald Dörflinger · Jim Fawcett • Georgios Fyttis • \\ Alexandros Galanidis • Bella Galil • Thomas Hadjikyriakou • Margarita Hadjistylli • \\ Christina Ieronymidou $\cdot$ Carlos Jimenez $\cdot$ Paraskevi Karachle • \\ Nikos Kassinis • George Kerametsidis • Alexander N. G. Kirschel • \\ Periklis Kleitou • Demetris Kleitou • Paraskevi Manolaki • Nikolas Michailidis • \\ J. Owen Mountford - Charis Nikolaou - Athina Papatheodoulou • \\ Giorgios Payiatas - Filipe Ribeiro - Stephanie L. Rorke - Yianna Samuel • \\ Pantelis Savvides • Stefanie M. Schafer • Ali Serhan Tarkan • Iolanda Silva-Rocha • \\ Nildeniz Top • Elena Tricarico • Katherine Turvey • Iakovos Tziortzis • \\ Elli Tzirkalli • Hugo Verreycken • Ian J. Winfield • Argyro Zenetos • \\ Helen E. Roy
}

Received: 10 September 2018/Accepted: 11 March 2019/Published online: 16 April 2019

(C) The Author(s) 2019

Electronic supplementary material The online version of this article (https://doi.org/10.1007/s10530-019-01961-7) contains supplementary material, which is available to authorized users.

Jodey Peyton and Angeliki F. Martinou: Joint first authors.

J. Peyton $(\varangle) \cdot$ O. L. Pescott · M. Botham .

H. J. Dean · J. O. Mountford · S. L. Rorke ·

S. M. Schafer · K. Turvey · H. E. Roy

Centre for Ecology and Hydrology,

Wallingford OX10 8BB, UK

e-mail: joyt@ceh.ac.uk

A. F. Martinou - J. Fawcett

Joint Services Health Unit Cyprus, BFC RAF Akrotiri BFPO 57, Akrotiri, Cyprus

M. Demetriou $\cdot$ N. Chartosia $\cdot$ A. C. Dimitriou

G. Fyttis · A. N. G. Kirschel · Y. Samuel · P. Savvides Department of Biological Sciences, University of Cyprus, 1 Panepistimiou Avenue, 2109 Nicosia, Cyprus

\author{
Abstract Invasive alien species (IAS) are one of the \\ major drivers of change that can negatively affect \\ biodiversity, ecosystem functions and services and \\ human health; islands are particularly vulnerable to \\ biological invasions. Horizon scanning can lead to \\ T. Adriaens · H. Verreycken \\ Research Institute for Nature and Forest (INBO), Herman \\ Teirlinckgebouw, Havenlaan 88bus 73, 1000 Brussels, \\ Belgium \\ M. Arianoutsou · I. Bazos · P. Delipetrou \\ G. Kerametsidis \\ Department of Ecology and Systematics, Faculty of \\ Biology, School of Sciences, National and Kapodistrian \\ University of Athens, 15784 Athens, Greece \\ C. W. Bean \\ Scottish Natural Heritage, Caspian House, Mariner Court, \\ Clydebank Business Park, Clydebank G81 2NR, UK
}


prioritisation of IAS to inform decision-making and action; its scale and scope can vary depending on the need. We focussed on IAS likely to arrive, establish and affect biodiversity and human health on the Mediterranean island of Cyprus. The scope of the horizon scanning was the entire island of Cyprus. We used a two-step consensus-building process in which experts reviewed and scored lists of alien species on their likelihood of arrival, establishment and potential to affect biodiversity, ecosystems and/or human health in the next 10 years. We reviewed 225 alien species, considered to be currently absent on Cyprus, across taxa and environments. We agreed upon 100 species that constituted very high, high or medium biodiversity risk, often arriving through multiple pathways of introduction. The remaining 125 species were ranked as low risk. The potential impacts on human health were documented for all 225 species; 82 species were considered to have a potentially negative impact on human health ranging from nuisance to disease transmission. The scope of the horizon scanning was the entire island of Cyprus, but the thematic groups also considered the relevance of the top 100 species to the Sovereign Base Areas of Cyprus, given their differing governance. This horizon scan provides the first systematic exercise to identify invasive alien species of potential concern to biodiversity and ecosystems but also human health within the Mediterranean region. The process and outcomes should provide other islands in the region and beyond with

\section{O. Booy}

Animal and Plant Health Agency, Sand Hutton,

York YO41 1LZ, UK

\section{J. R. Britton}

GB Bournemouth University, Christchurch House C238b, Talbot Campus, Fern Barrow, Poole BH12 5BB, UK

\section{J. L. Cervia}

National Museum of Natural Sciences, Calle. de José Gutierrez Abascal, 2, 28006 Madrid, Spain

P. Charilaou - T. Hadjikyriakou

Akrotiri Environmental Education Centre, Queen

Elizabeth Street, 4640 Akrotiri Village, Lemesos, Cyprus

G. Dörflinger · I. Tziortzis

Water Development Department, Ministry of Agriculture, Rural Development and Environment, Kennedy Avenue 100-110, Pallouriotissa, 1047 Nicosia, Cyprus baseline data to improve IAS prioritisation and management.

Keywords Consensus approach · Cyprus - Levant . Non-native species $\cdot$ Pathways $\cdot$ Prioritisation

\section{Introduction}

The threat from invasive alien species (IAS) as one of the main drivers of biodiversity change is increasing as the number of alien species arriving in countries around the globe is rising with no sign of saturation (Seebens et al. 2017). Islands are particularly vulnerable to biological invasions (Simberloff 1995; Jeschke 2008). Species on islands often persist within small populations with restricted genetic diversity and this, coupled with often limited habitat availability on islands, increases their vulnerability to perturbation by anthropogenic factors, including the introduction of IAS (Russell et al. 2017). Horizon scanning to identify likely future invasions of IAS is, therefore, pivotal for prioritising action and mitigating the negative effects of introduced species on islands. Horizon scanning is an approach used to prioritise the threat posed by potentially new IAS not yet established within a region, and has been seen as an essential component of IAS management with demonstrated net economic and ecological benefits (Keller et al. 2007; Shine et al.
A. Galanidis
Biodiversity Conservation Laboratory, Department of Environment, University of the Aegean, 81100 Mytilene, Lesbos, Greece
B. Galil
The Steinhardt Museum of Natural History, Tel Aviv University, Tel Aviv, Israel
M. Hadjistylli
Department of Environment, Ministry of Agriculture, Rural Development and Environment, 1498 Nicosia Cyprus, P.O. Box 27658, 2432 Nicosia, Cyprus
C. Ieronymidou
Birdlife Cyprus, P.O Box 12026, 2340 Nicosia, Cyprus
C. Jimenez
Enalia Physis Environmental Research Centre, Acropoleos 2, Aglantzia, 2101 Nicosia, Cyprus 
2010; Caffrey et al. 2014; Roy et al. 2015). The approaches adopted by Roy et al. (2014a) are starting to be applied more widely within Europe (Gallardo et al. 2016; Roy et al. 2015, 2019).

Cyprus provides an interesting context for applying IAS horizon scanning approaches. The Republic of Cyprus as a member of the European Union (EU) is obliged to adopt the Regulation on IAS; however, due to the de facto partitioning of the island, EU law is not applied to the areas where the Government of the Republic does not exercise control. Furthermore, with some exceptions, EU legislation does not apply to the UK Sovereign Base Areas (SBAs) of Akrotiri and Dhekelia, which are not under the sovereignty of the Republic of Cyprus. As a result, the application of measures to protect biodiversity and the establishment of common conservation and management goals across the island is challenging. In particular, the efficacy of measures to manage IAS, including prevention, will depend on initiatives agreed and applied across the entire island. Many such initiatives depend on prioritised lists of alien species (Roy et al. 2014b).

The Mediterranean is a well-known biodiversity hotspot (Myers et al. 2000; Coll et al. 2010), and within that Cyprus harbours important biodiversity, with high degrees of endemism across taxa (Sparrow and John 2016). For example, six out of the 11 wild mammals, excluding the 19 bat species, are considered endemic (Sparrow and John 2016), and the level of

P. Karachle $\cdot$ A. Zenetos

Hellenic Centre for Marine Research, Institute of Marine Biological Resources and Inland Waters,

19013 Anavyssos, Greece

N. Kassinis

Game and Fauna Service, Ministry of Interior,

1453 Nicosia, Cyprus

P. Kleitou · D. Kleitou

Marine and Environmental Research (MER) Lab, 202

Amathountos Av, Marina Gardens, Block B, Off. 13-14, Limassol, Cyprus

P. Manolaki

Open University of Cyprus, B1 33, 2220 Latsia, Cyprus

P. Manolaki

Institute for Bioscience, Bioscience Aarhus, Aarhus

Universitet, Ny Munkegade 114 - 116, 8000 Aarhus,

Denmark endemism for plants (113 species), around 7\% of the indigenous flora (Christodoulou 2003; Tsintides et al. 2007), is among the highest in the European Union. IAS are considered one of the major current threats to biodiversity of ecosystems in Cyprus (Hadjikyriakou and Hadjisterkotis 2002; Christodoulou 2003). For example, IAS exert an additional pressure on Cypriot freshwater and salt marsh ecosystems that are already threatened by aquaculture, water extraction, climate change, drainage, the building of dams, and mosquito management, including the use of chemicals or the release of invasive alien mosquitofish Gambusia species (Sparrow and John 2016).

Traditionally ecologists and invasion biologists have solely focused on the impacts of IAS on biodiversity and ecosystem functions. The adoption of a more anthropocentric approach, that of ecosystem services (Vilà and Hulme 2017), where biodiversity is considered within the context of human well-being, has highlighted the need to consider the human health impacts of IAS alongside environmental impacts. Most forecasts of the risk of emerging diseases have largely neglected the potential role of alien species (Hulme 2014; Roy et al. 2017; Galil 2018). One Health initiatives (www.onehealthinitiative.com, accessed 08/2018) aim to bring an interdisciplinary approach to the health of people, domestic animals and wildlife, and it has been suggested that such an approach is key to understanding, detecting, and managing the emergence of both alien pathogens,

P. Manolaki

Aarhus Institute of Advanced Studies (AIAS), Høegh-

Guldbergs Gade 6B, 8000 Aarhus, Denmark

N. Michailidis · G. Payiatas

Department of Fisheries and Marine Research, Ministry of

Agriculture, Rural Development and Environment,

Amfipoleos 6, Strovolos, 2025 Nicosia, Cyprus

C. Nikolaou

Department of Forests, P.O. Box 24136, 1414 Nicosia, Cyprus

A. Papatheodoulou

I.A.CO Environmental and Water Consultant Ltd, Stavrou

3, 2035 Strovolos, Cyprus

F. Ribeiro

MARE, Centro de Ciências do Mar e do Ambiente,

Faculdade de Ciências, Universidade de Lisboa, Lisbon, Portugal 
pathogens associated with alien species, and their impacts across borders and hosts (Roy et al. 2017). Knowledge on human health impacts is an important consideration for risk assessment and decision-making on IAS, but is currently biased towards only a few species, and impacts are generally poorly understood (Schindler et al. 2015). The impacts of IAS on human health vary from psychological effects, discomfort, nuisance and phobias, to skin irritations, allergies, poisoning, disease and even death (Bayliss et al. 2017; Martinou and Roy 2018).

While recognising that the gaps in knowledge on alien pathogens prohibit systematic consideration across all potential hosts, we recognised an opportunity to consider human health impacts based on expert opinion, even if it is necessary to attribute low confidence to the predictions. Here, for the first time in a horizon scanning exercise, we considered human health effects alongside ecological impacts to derive a list of IAS that are likely to arrive, establish and have an impact on biodiversity, ecosystems and human health within the next 10 years across the entire island of Cyprus.

\section{Methods}

Study region

The scope of the horizon scanning was the entire island of Cyprus, but the thematic groups also considered the relevance of the top 100 species to the Sovereign Base Areas of Cyprus, given their differing governance.

Cyprus, located in the Levantine Basin (eastern Mediterranean), is situated $75 \mathrm{~km}$ from the Turkish mainland in the north, $150 \mathrm{~km}$ from Syria in the east and $380 \mathrm{~km}$ from Egypt in the south, while in the west

A. S. Tarkan - N. Top

Faculty of Fisheries, Muğla Sitkı Koçman University, 48000 Kötekli, Muğla, Turkey

A. S. Tarkan

Department of Ecology and Vertebrate Zoology, Faculty of Biology and Environmental Protection, University of Łódź, Lodz, Poland

I. Silva-Rocha

Research Center in Biodiversity and Genetic Resources (CIBIO), Campus de Vairão, Rua Padre Armando

Quintas, $n^{\circ}$ 7, 4485-661 Vairão, Portugal the closest shores are the Greek islands of Karpathos and Rhodes at $380 \mathrm{~km}$ (Delipetrou et al. 2008). It has an extreme Mediterranean climate, with an average rainfall of $480 \mathrm{~mm}$ per year that places it among the top 20 water-deprived countries worldwide (Myers and Haines 2000).

The horizon scanning process involved three stages:

1. Determination of composition and scope of thematic groups

2. Preliminary consultation between experts within four thematic groups (plants, freshwater animals, terrestrial animals, and marine species), excluding microorganisms.

3. Consensus-building across the thematic groups

\section{Composition and scope of the thematic groups}

Experts for the thematic groups were invited based on their breadth of taxonomic and invasion ecology knowledge. Some of the experts had previous experience in horizon scanning. Many of the participants had specific expertise in the Mediterranean environment within both Cyprus but also neighbouring countries. The experts were allocated to the thematic groups based on their expertise which overall provided comprehensive coverage of taxa and environments (terrestrial, freshwater and marine). The scope of each thematic group was clearly defined and conveyed to all participants. Participants were instructed to include a species if they had any doubt regarding its allocation; brackish species, for example, were considered by more than one group, with information pooled during the plenary sessions.

Each of the four groups had at least two co-leaders (scientists with relevant ecological and invasion

E. Tricarico

Department of Biology, University of Florence, Via

Romana 17, 50125 Florence, Italy

\section{E. Tzirkalli}

Department of Biological Applications and Technology, University of Ioannina, 45110 Ioannina, Greece

\section{J. Winfield}

Lake Ecosystems Group, Centre for Ecology and Hydrology, Lancaster LA1 4AP, UK 
biology expertise) from Cyprus or the eastern Mediterranean and one international expert. Additionally, there were between six to eleven additional group participants selected by the group leaders on the basis of their experience in the field of IAS. Twenty-four participants from across Cyprus and 27 from the rest of Europe participated in this exercise from a variety of backgrounds: academia, private consultancies, government and the military.

\section{Pre-workshop research and preparation}

Each of the four thematic groups was given the task of collating a list of alien species that were considered likely to arrive within the next decade, to establish and have an impact on native biodiversity, ecosystems and/or human health. Lists generated from a previous EU horizon scanning exercise (Roy et al. 2014a, 2015) were circulated to all groups. The groups were instructed to assess these lists for relevance to Cyprus, removing and adding species as appropriate. The thematic groups did not compile a comprehensive list of all the sources consulted but derived information from various sources including peer-reviewed papers or inventories (Georgiades 1994; Hadjikyriakou and Hadjisterkotis 2002; Katsanevakis et al. 2009; Arianoutsou et al. 2010), online information, and expert opinion. Over a 6-week period the thematic groups completed this preliminary exercise by communicating through email, telephone and video-conferencing. In addition to compiling the lists, the thematic groups populated a spreadsheet template (Supplementary information 1), which included agreed scores on likelihood of arrival, establishment, spread and impact on biodiversity, ecosystems, and human health within each thematic group in advance of the workshop.

The spreadsheet template included the following headings for gathering information on a species' basic biology: taxon, common name(s), taxonomic group, functional group, native distribution, presence in the EU and thematic group. Likelihood of arrival, likelihood of establishment, and likelihood of impact on biodiversity were all scored on a scale of 1 (very unlikely) to 5 (very likely). As with Roy et al. (2014a), the overall score for each species was determined as the product of the scores for likelihood of arrival, establishment and impact on biodiversity (maximum score $=125)$, and the confidence in the overall score was expressed as low, medium or high. For scoring of confidence: Low $(\mathrm{L})=$ no direct observational evidence is available or evidence is difficult to interpret or considered low quality; Medium (M) = some direct observational evidence is available but may be ambiguous or difficult to scale within the specific geographic context; High $(\mathrm{H})=$ direct observational evidence is available and straightforward to interpret without controversy and considered high quality. Impacts on biodiversity were assessed by considering the following four parameters and their sub-categories (Branquart 2009; Vanderhoeven et al. 2015): dispersal potential (indicating potential to spread); colonisation of high conservation-value habitats; adverse impacts on native species (predation/herbivory, competition, transmission of pathogens and parasites to native species, genetic effects); and alteration of ecosystem functions (modification to nutrient cycling, physical modifications to the habitat, modifications of natural successions, disruption of food webs). Human health impacts were classified using the following categories: no impact, nuisance (including psychological effects), disease transmission, parasitism and poisoning/toxicity/allergy and other impacts such as IAS facilitating negative impacts on human health by other species (Table 1). A species could be attributed multiple human health impacts. Additional information, specifically within the context of Cyprus, was compiled on the likely pathways of arrival, types of biodiversity impact, impact mechanisms on other species, impact mechanisms on ecosystem function, impact on human well-being, socio-economic impacts, additional comments and references. The participants were given guidance notes on completing the spreadsheet (Supplementary Information 2).

\section{Consensus building across thematic groups}

Consensus building across the thematic groups took place at a workshop held at the Akrotiri Environmental Education and Information Centre in the Akrotiri Sovereign Base Area, Cyprus on the 28th April 2017. Each thematic group provided an overview of their high-ranking species. The thematic groups were then given the opportunity to revise scores and ranks following the overviews of the other thematic groups in order to moderate approaches to scoring across groups. The thematic groups subsequently re-convened, and, through discussions, consensus was 
Table 1 Definitions of the human health impact categories used in this study with an illustrative example

\begin{tabular}{|c|c|c|}
\hline $\begin{array}{l}\text { Human health } \\
\text { impact }\end{array}$ & Definition & Example \\
\hline $\begin{array}{l}\text { 1. No impact on } \\
\text { human health }\end{array}$ & No known adverse effects on human health & The Northern Brown Shrimp Penaeus aztecus \\
\hline 2. Nuisance & $\begin{array}{l}\text { Inflicting negative effects on human well-being } \\
\text { including psychological }\end{array}$ & Noise by frogs and toads, fear of snakes even if harmless \\
\hline $\begin{array}{l}\text { 3. Disease } \\
\text { transmission e.g. } \\
\text { mosquito vectors }\end{array}$ & Vectoring pathogens that can cause diseases & $\begin{array}{l}\text { Yellow fever, Zika virus, dengue, chikungunya, } \\
\text { transmitted by mosquito vectors Aedes aegypti and } \\
\text { Aedes albopictus }\end{array}$ \\
\hline $\begin{array}{l}\text { 4. Poisoning, } \\
\text { toxicity, allergy, } \\
\text { injury }\end{array}$ & $\begin{array}{l}\text { Humans exposed to IAS may experience direct } \\
\text { negative effects through bites, stings, allergens, } \\
\text { harm, affliction }\end{array}$ & $\begin{array}{l}\text { Alien plants with allergenic pollen Invasive Hymenoptera } \\
\text { such as the Asian Hornet Vespa velutina, Lionfish } \\
\text { Pterois miles, catfish Plotosus lineatus }\end{array}$ \\
\hline $\begin{array}{l}\text { 5. Others e.g. } \\
\text { interactions with } \\
\text { other IAS }\end{array}$ & IAS facilitating negative impacts & $\begin{array}{l}\text { Indian house crow Corvus splendens as a host species, and } \\
\text { mosquitoes which have a role in transmission of West } \\
\text { Nile Virus (WNV) }\end{array}$ \\
\hline
\end{tabular}

achieved on the ranking of the top 100 species across all thematic groups.

After the workshop, the thematic groups were given the opportunity to review the list and specifically check the establishment status of the species and provide additional supporting information, including evidence of impacts and known or likely pathways; this final dataset is the one presented and analysed here. The likely pathways of arrival for each IAS were documented using the Convention of Biological Diversity terminology (CBD 2014; Harrower et al. 2018); Supplementary Information 3 lists these category definitions. The human health impacts for all taxa were also reviewed post-workshop by one of the authors (AFM). This ensured that human health impacts were comprehensively assigned based on available evidence including peer-reviewed sources but also grey literature where knowledge gaps exist.

\section{Results}

Two-hundred and twenty-five species across all thematic groups were combined into a long list for consideration during the workshop (Supplementary Information 3); the plant thematic group compiled additional information on impacts after the consensus workshop (Supplementary Information 4). The group reached consensus on the ranking of the top 100 species within the following bands: 1-20, 21-40,
41-100. All species ranked during the horizon scanning workshop were considered to be of relevance to the entire island of Cyprus, including the British SBAs. The top 20 species had the maximum score of 125 (Tables 2, 3) and are subsequently referred to as presenting 'very high' potential future risk to the island.

Among the top 20 species that received the highest score were two plants, ten terrestrial animals (two insects, three birds and five mammals), four marine species and four freshwater species (Tables 2, 3). We ranked a further 20 species as presenting a potential future high risk (species scoring 100), 64 as medium risk (species scoring 60-80) and 121 as low risk species (species scoring less than 60). This information is detailed in Supplementary Information 3.

A high proportion of the species predicted to impact biodiversity were also considered likely to impact on human health (Fig. 1). Sixty percent of the species with very high negative biodiversity impacts are known to be involved in the transmission of pathogens or diseases. Of the species that have high impacts on biodiversity, $40 \%$ of these are involved in disease transmission of some sort. Of these species, $20 \%$ are involved in a nuisance effect, such as noise for example, and $16 \%$ in direct negative health effects through poisoning, toxicity, allergies, bites or injuries (Fig. 1). The impact on human health was lower for IAS ranked as high, medium and low to biodiversity: $40 \%, 39 \%$ and $29 \%$ respectively. 


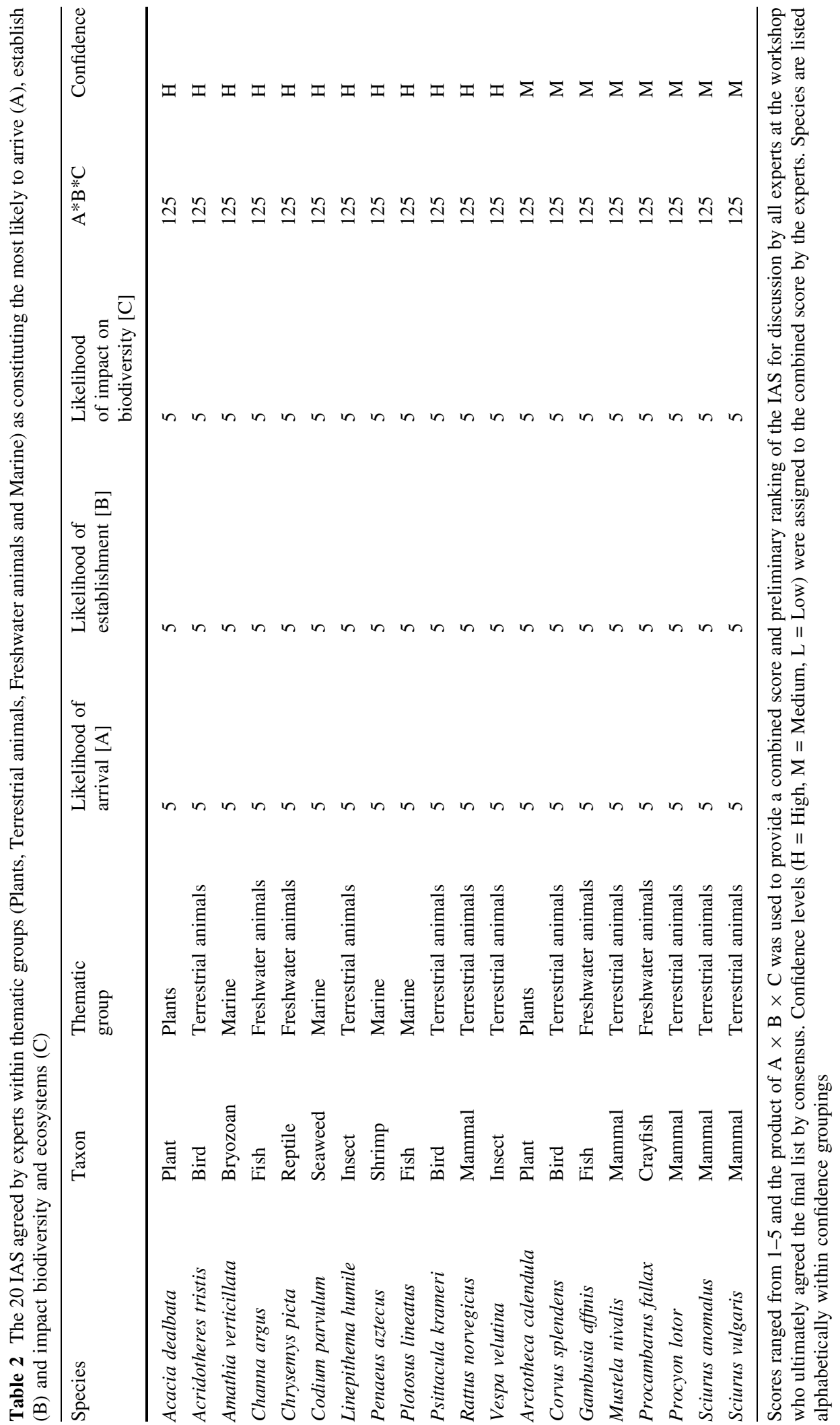


Table 3 The 20 IAS agreed by experts within thematic groups (Plants, Terrestrial animals, Freshwater animals and Marine) as constituting the most likely to arrive, establish and impact biodiversity and ecosystems alongside the impact mechanisms for biodiversity, ecosystem function and human health (where human health impacts were identified)

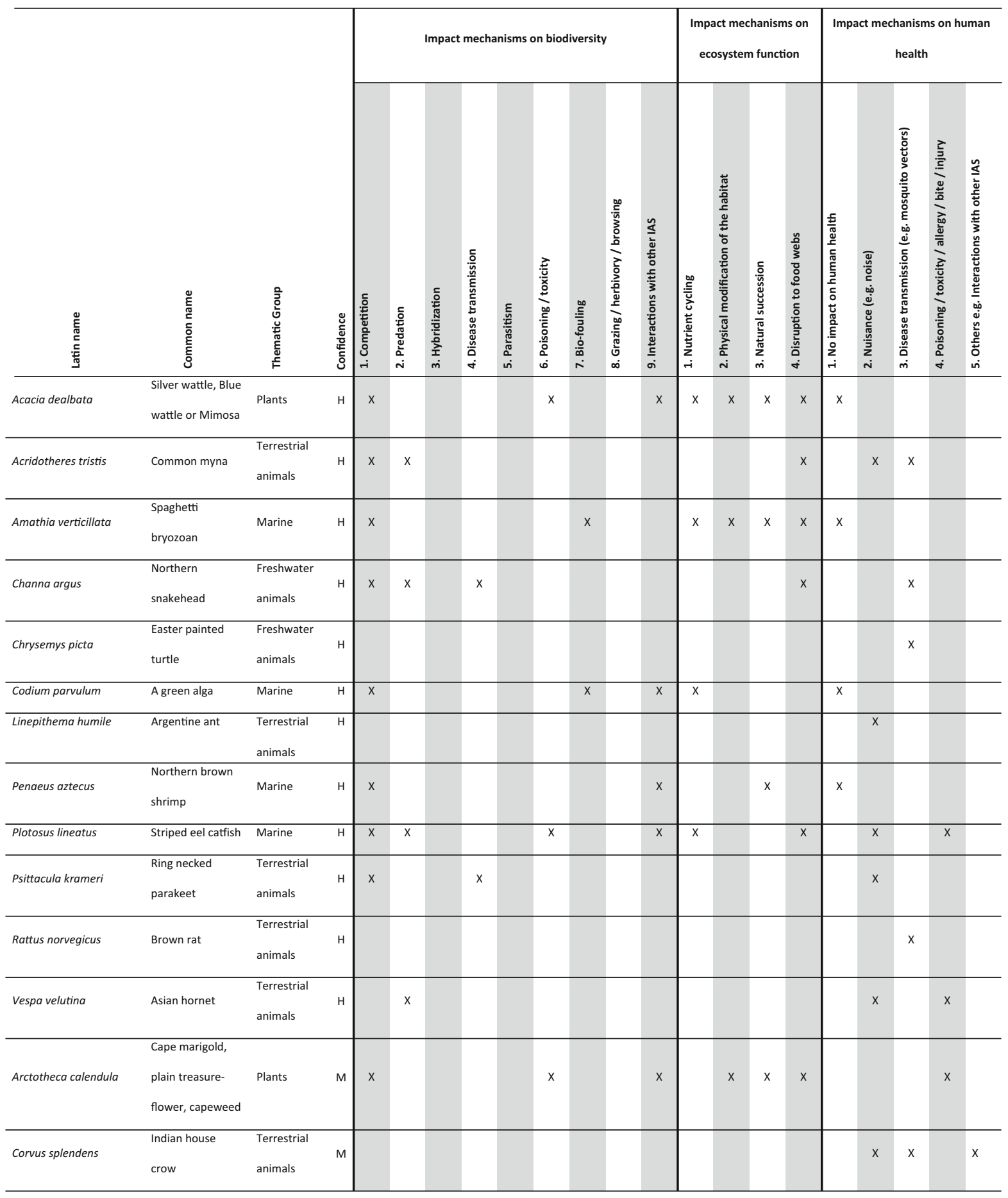


Table 3 continued

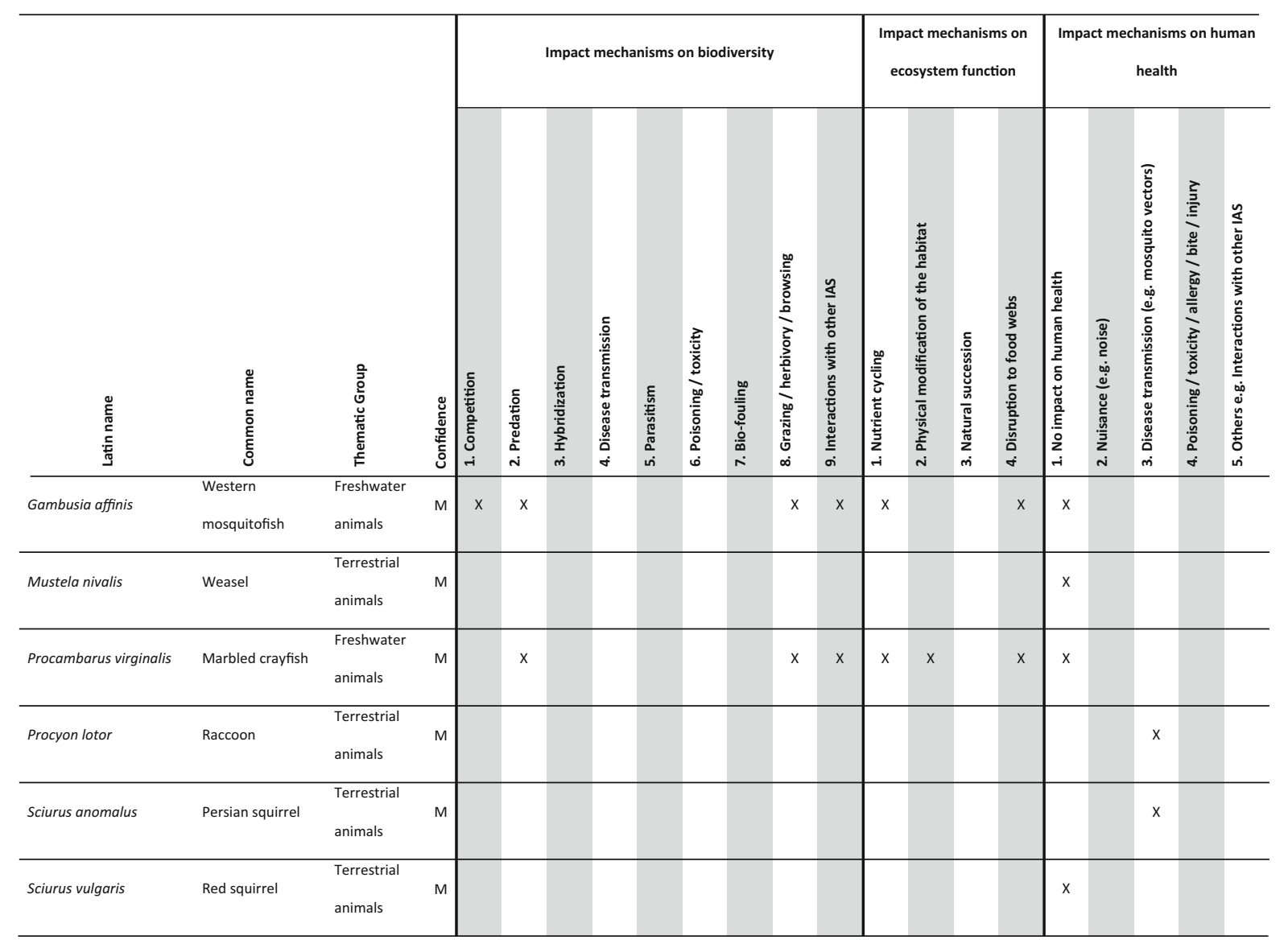

Species are listed alphabetically within confidence groupings

\section{Arrival pathways}

Thirty-eight different arrival pathways at the Convention on Biological Diversity (CBD) subcategory level (see Supplementary Information 2 for full list) were assigned across the species listed (Supplementary Information 3). Freshwater animals had the highest overall number of pathways (12) attributed to their likely arrival, with plants and marine macrophytes, terrestrial animals species having the lowest number of arrival pathways (4) (Fig. 2). Even though freshwater animals had the highest number of pathways associated with their predicted arrival, it was more common for only one pathway type to be attributed to a freshwater animal species than multiple pathways, although across all groups 104 species had two or more likely pathways through which they could arrive.
Terrestrial animals, categorised as likely to have a very high or high impact on biodiversity, were considered likely to arrive through up to four pathways with a high proportion arriving by either one or two different pathways, such as the pet trade or escapes from zoos (Fig. 2). Plants are most likely to arrive through one or two pathways (with horticulture and forestry dominating) (Fig. 2). Similarly, only one or two pathways, particularly hull fouling and ballast water, are considered relevant for the majority of marine species, particularly those predicted to have the highest threat to biodiversity (Fig. 2). At the CBD level I category, escape was the dominant pathway across all biodiversity impact categories (Fig. 3). The pathways stowaway and corridor were the second most common pathways but these tended to be associated with species predicted to have low impact. 


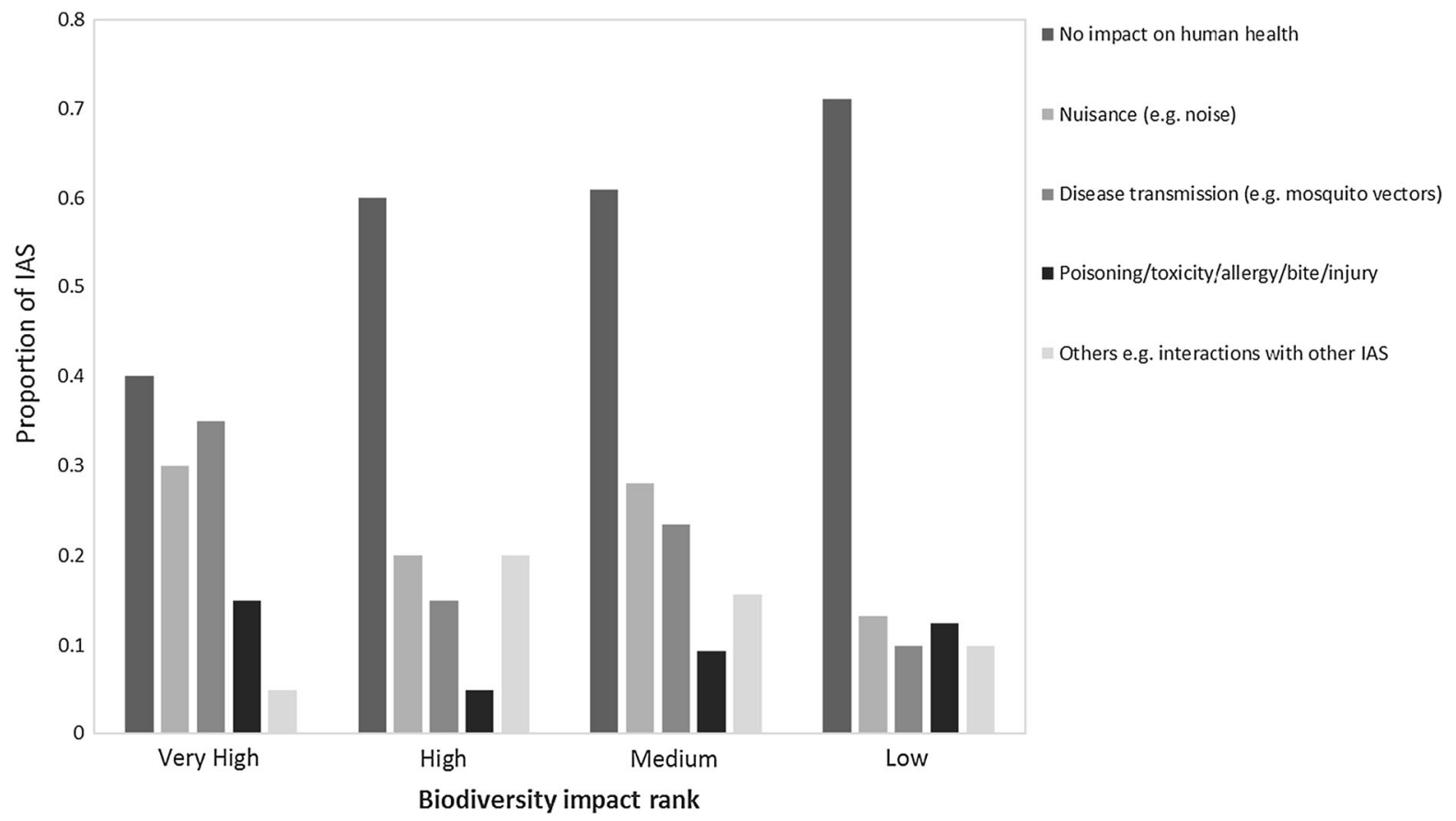

Fig. 1 Proportion of IAS ranked as very high, high, medium or low threat to biodiversity and ecosystems that either have no impact on human health or pose a threat to human health through

Pathways relating to food, botanical gardens, zoological parks and aquaria, horticulture and the pet trade are the main routes for species considered to have high impact on biodiversity (Fig. 4). Terrestrial animals and plants are predicted to be more likely to escape from captivity than marine species and freshwater animals (Fig. 5). Considering the escape pathway in more detail highlights that species kept as pets or in zoos and gardens are the most likely sources of escape for plants and terrestrial animals (Fig. 5). In contrast, pathways associated with ship movements (hull and ballast water contaminants) and natural dispersal through spread of IAS from existing invaded regions are anticipated to be the most likely sources of invasion for the marine environment, whereas food, pet, shipping, angling and aquaculture are the most likely for freshwater species (Fig. 5).

\section{Discussion}

It is widely accepted that IAS affect not only biodiversity and ecosystems but also socio-economic factors (Shine et al. 2010). However, assessment of the nuisance, disease transmission, poisoning/toxicity/allergy/bite/ injury or other human health impact

risks of IAS most often focus only on biodiversity, and sometimes also ecosystem function but there is a need for interdisciplinary approaches that embrace the concept of ecosystem services including human well-being (Vilà and Hulme 2017). In an attempt to address this need we developed a horizon scanning approach that considered the potential threat posed by IAS, predicted to arrive and establish on Cyprus, to biodiversity and ecosystems alongside human health. The vast array of information collated by the experts for many species highlights the complexity of the task. However, sufficient commonalities were apparent to enable experts from different disciplines to agree a prioritised list of IAS that were relevant at the scale of the entire island but also the SBAs, which have different governance. Following a method that included simple and transparent scoring criteria enabled experts from disparate disciplines to consider both human health, biodiversity and ecosystem impacts. Such an interdisciplinary approach should provide decision-makers with the necessary evidence to prioritise species for risk assessment (Roy et al. 2018a, b), ultimately leading to the development and implementation of pathway and management plans at 

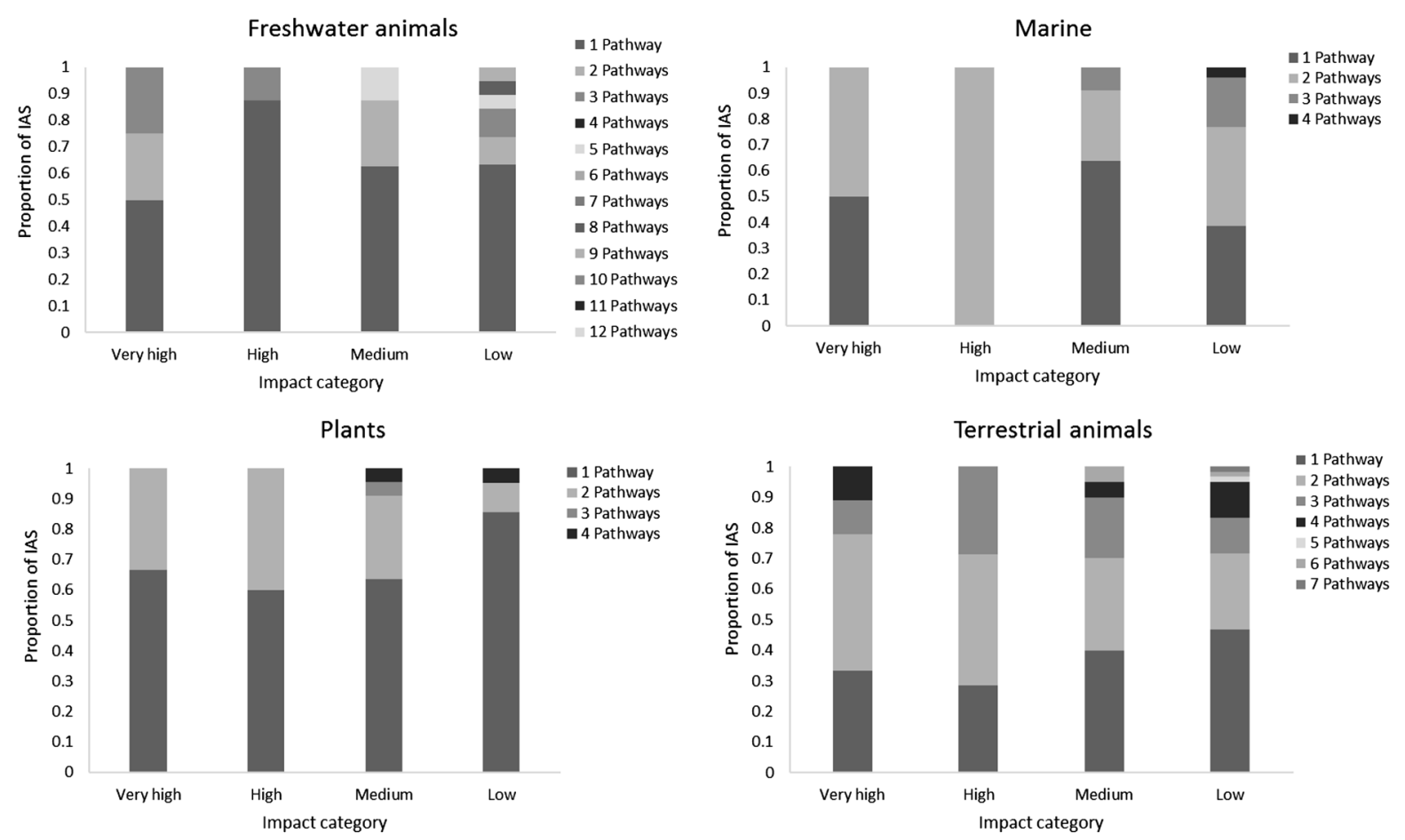

Fig. 2 Proportion of IAS within the four thematic groups (Freshwater animals, Marine, Plants, Terrestrial animals) ranked as very high, high, medium or low threat to biodiversity and ecosystems that are predicted to arrive through either one or

multiple pathways of introduction (up to four for IAS identified through the Marine and Plants thematic groups or up to seven and 12 for Terrestrial animals and Freshwater animals respectively)

Fig. 3 Proportion of IAS ranked as very high, high, medium or low threat to biodiversity and ecosystems predicted to arrive through the CBD level I pathways of introduction: Contaminant, Corridor, Escape, Release, Stowaway or Unaided
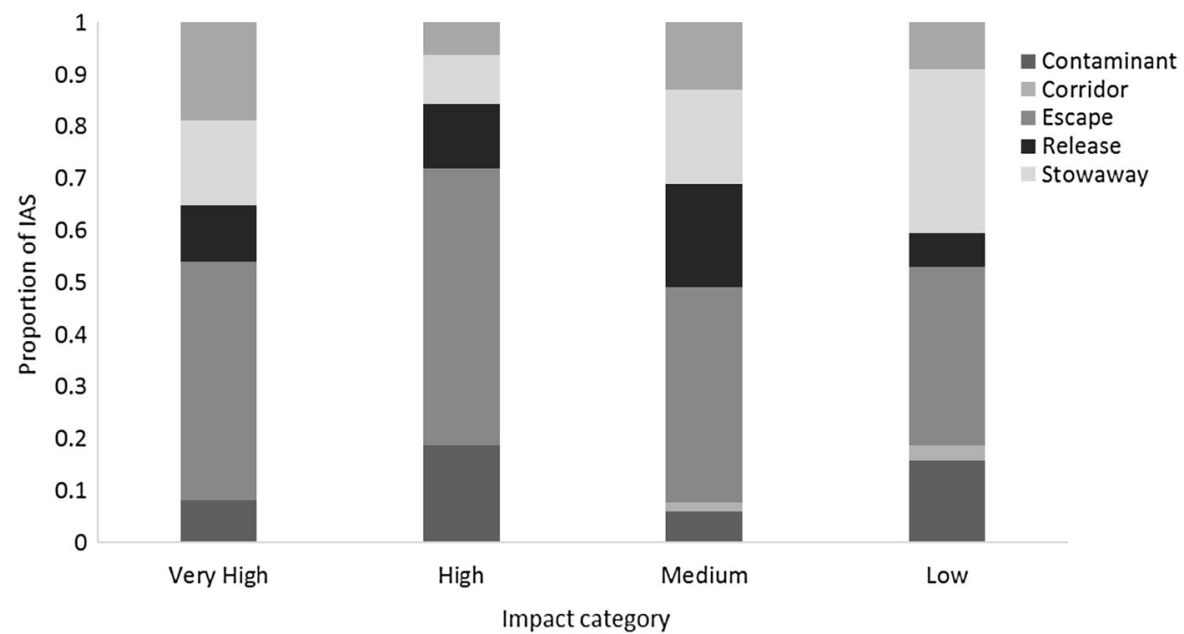

various spatial scales, including the UK Sovereign Base Areas (SBAs) of Akrotiri and Dhekelia through to the wider island of Cyprus.

The IAS identified through our horizon scanning exercise spanned terrestrial, freshwater and marine environments; terrestrial IAS dominate the list and constitute over half of the species within the top 100 . While freshwater habitats on Cyprus are limited and only 26 freshwater IAS were identified as a threat, it is important to note these that freshwater environments are particularly sensitive to invasion (Havel et al. 2015; Tricarico et al. 2016) and harbour important 


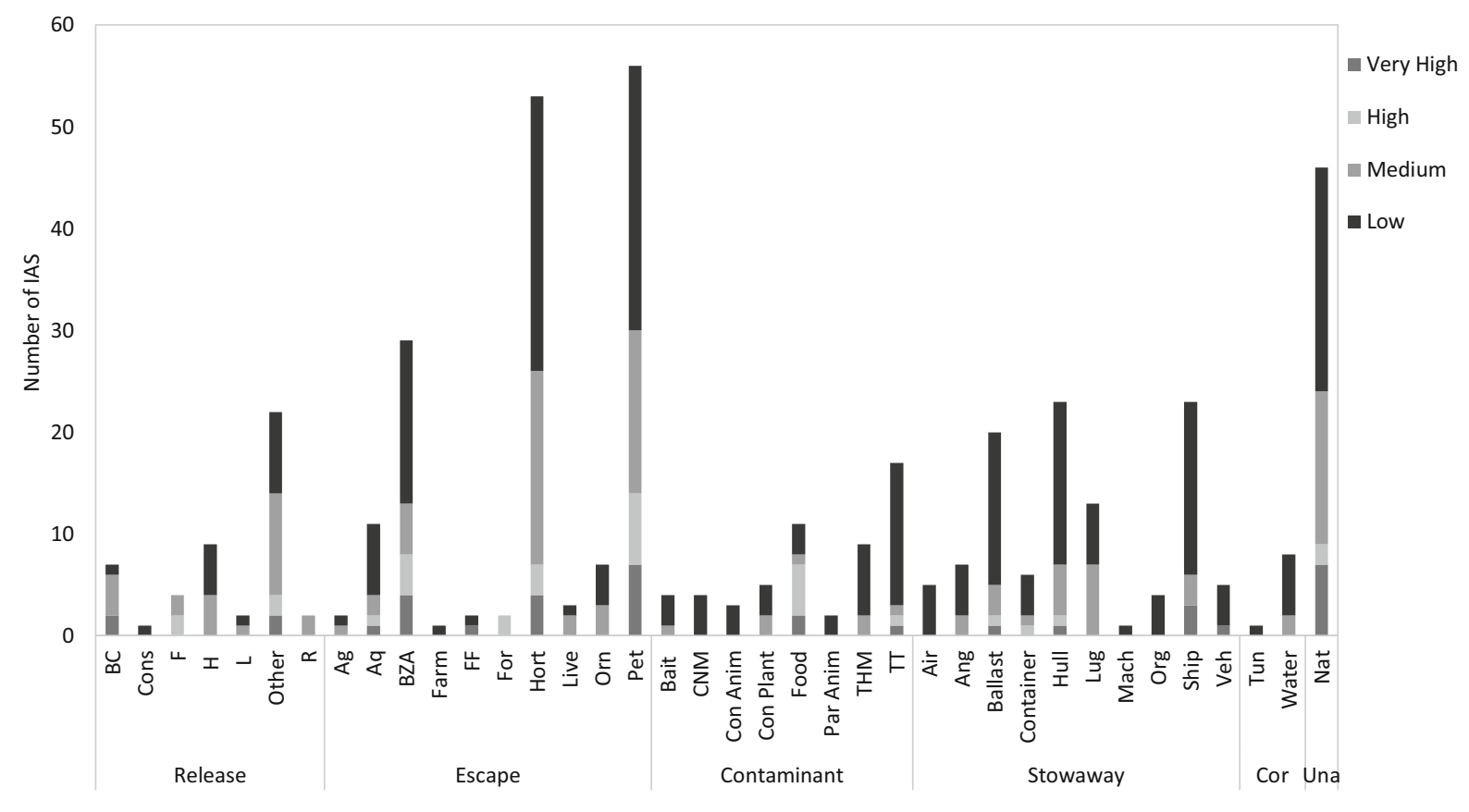

CBD level I and II categories

Fig. 4 Number of IAS ranked as very high, high, medium or low threat to biodiversity and ecosystems predicted to arrive through the CBD level II pathways of introduction and represented within their overarching CBD I category: Release: $\mathrm{BC}=$ Biological control; Cons = Introduction for conservation purposes or wildlife management; $\mathrm{F}=$ Fishery in the wild; $\mathrm{H}=$ Hunting; L = Landscape/flora/fauna "improvement" in the wild; Other $=$ Other escape from confinement; $\mathrm{R}=\mathrm{Re}$ search and ex situ breeding; Escape: $\mathrm{Ag}=$ Agriculture; $\mathrm{Aq}=$ Aquaculture/mariculture; BZA = Botanical garden/zoo/ aquaria; Farm $=$ Farmed animals; $F F=$ Fur farms; For $=$ Forestry; Hort = Horticulture; Live $=$ Live food and live bait; Orn = Ornamental purpose other than horticulture; Pet $=$ Pet $/$ aquarium/terrarium species; Contaminant: Bait $=$ Contaminated bait; $\mathrm{CNM}=$ Contaminant nursery material; Con

biodiversity (Gucel et al. 2012). Furthermore, there are a number of factors, in addition to IAS, that are adversely affecting freshwater biodiversity including aquaculture, water extraction and climate change. Within the marine environment 16 IAS were considered to pose a potential threat. There has been an increase in the arrival of marine IAS to the Mediterranean following the opening and periodic widening of the Suez Canal. These so-called Lessepsian migrant species are arriving from the Red Sea into the Levantine Basin (eastern Mediterranean) where Cyprus is situated. However, fouling of ships, ballast water exchange, aquaculture, and the aquarium trade are also responsible for the introduction of IAS into
Anim = Contaminant on animals; Con Plant $=$ Contaminant on plants; Food = Food contaminant; Par Anim = Parasites on animals; THM = Transportation of habitat material; TT $=$ Timber trade; Stowaway: Air = Hitchhikers in or on airplane; Ang = Angling/fishing equipment; Ballast $=$ Ship/boat ballast water; Container $=$ Container/bulk; Hull $=$ Ship/boat hull fouling; $\quad$ Lug = People and their luggage/equipment; Mach = Machinery/equipment; Org = Organic packing material, in particular wood packaging; Ship = Hitchhikers on ship/ boat; Veh = Vehicles; Corridor (Cor): Tun = Tunnels and land bridges; Water = Interconnected waterways/basins/seas); Unaided (Una): Nat $=$ Natural dispersal across borders of invasive alien species that have been introduced through pathways $1-5$

this region (Streftaris and Zenetos 2009). In 2008, it was estimated that the number of recorded alien species in the Mediterranean Sea was continuing to increase at a rate of one new record every 9 days (Zenetos et al. 2008; Katsanevakis et al. 2009). Latest reports (2010-2016), considering only multicellular alien species, indicate the rate of introductions is 11 species per year (Zenetos et al. 2017). The Mediterranean Sea, including Cyprus, can be considered an early-warning system for other European marine environments; it has been estimated that $76 \%$ of the first marine introductions of IAS across Europe were reported first from the Mediterranean Sea, with 54\% first reported in the eastern Aegean-Levantine Sea 


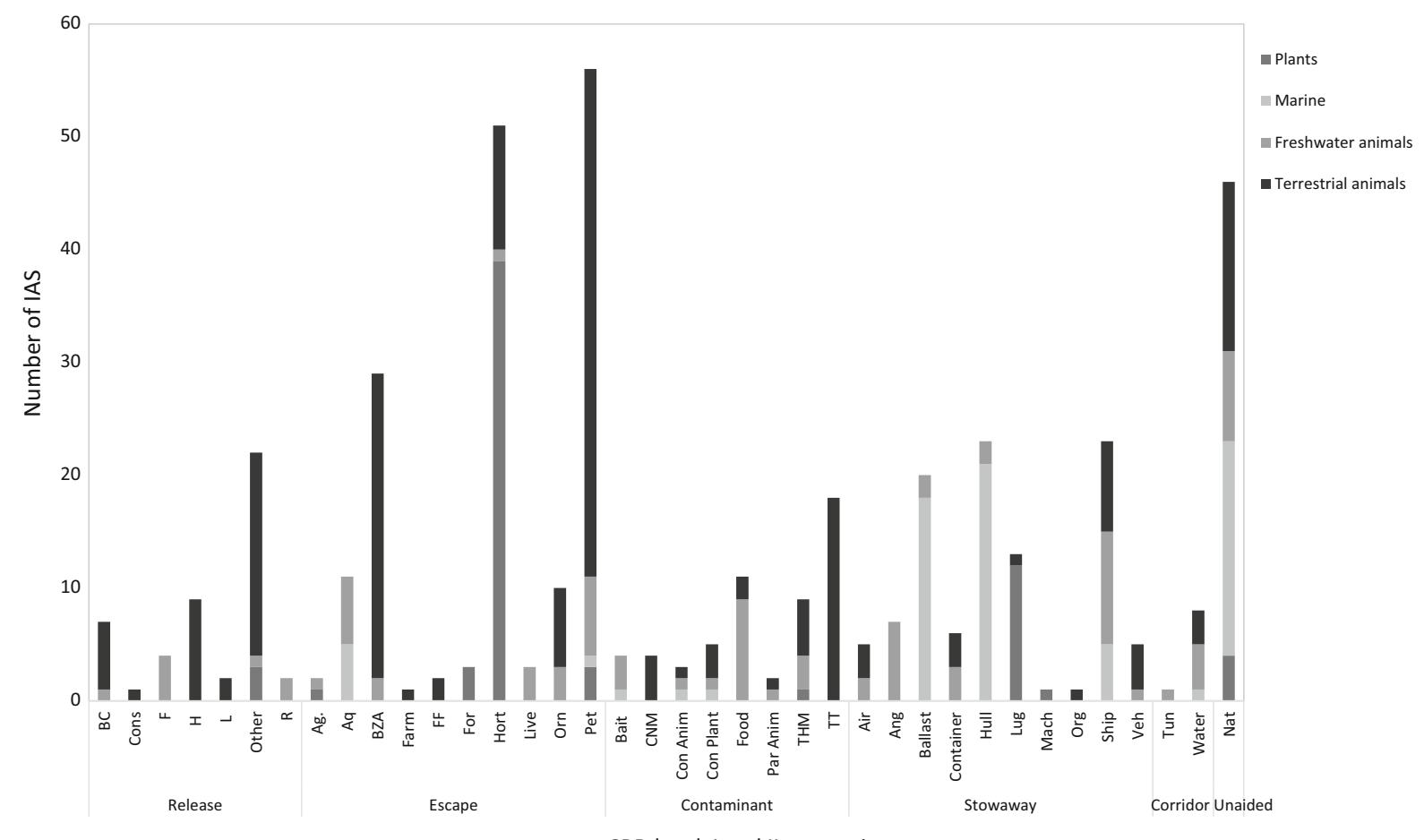

CBD level I and II categories

Fig. 5 Number of IAS across the four thematic groups (Plants, Marine, Freshwater animals and Terrestrial animals) ranked as very high, high or medium impact on biodiversity and ecosystems within the CBD subcategory pathways, and represented within their overarching CBD I category: Release: $\mathrm{BC}=$ Biological control; Cons = Introduction for conservation purposes or wildlife management; $\mathrm{F}=$ Fishery in the wild; $\mathrm{H}=$ Hunting; $\mathrm{L}=$ Landscape/flora/fauna "improvement" in the wild; Other = Other escape from confinement; $\mathrm{R}=$ Research and ex situ breeding; Escape: Ag = Agriculture; Aq = Aquaculture/mariculture; BZA = Botanical garden/zoo/aquaria; Farm $=$ Farmed animals $; \quad$ FF $=$ Fur farms $;$ For = Forestry; Hort $=$ Horticulture; Live $=$ Live food and live bait Orn $=$ Ornamental purpose other than horticulture; Pet = Pet/aquarium/ terrarium species; Contaminant: Bait $=$ Contaminated bait;

(Tsiamis et al. 2018). Management of marine invasions is known to be exceptionally difficult (Russell et al. 2017) and the feasibility of eradicating marine species is particularly low (Booy et al. 2017), preventing their arrival is therefore critical.

Invasive alien birds, ants, rodents and other mammals constitute some of the greatest threats to biodiversity (Jeschke 2008; Ward et al. 2008), and these are well-represented within our list. Many of these animals have serious impacts on biological diversity and/or human activities, such as common myna Acridotheres tristis, Argentine ant Linepithema
$\mathrm{CNM}=$ Contaminant nursery material; Con Anim = Contaminant on animals; Con Plant $=$ Contaminant on plants; Food = Food contaminant; Par Anim $=$ Parasites on animals; $\mathrm{THM}=$ Transportation of habitat material; $\mathrm{TT}=$ Timber trade; Stowaway: Air $=$ Hitchhikers in or on airplane; Ang = Angling/fishing equipment; Ballast $=$ Ship/boat ballast water; Container $=$ Container/bulk; Hull $=$ Ship/boat hull fouling; $\quad$ Lug = People and their luggage/equipment; Mach = Machinery/equipment; Org = Organic packing material, in particular wood packaging; Ship = Hitchhikers on ship/ boat; Veh = Vehicles; Corridor (Cor): Tun = Tunnels and land bridges; Water = Interconnected $\quad$ waterways/basins/seas); Unaided (Una): Nat $=$ Natural dispersal across borders of invasive alien species that have been introduced through pathways $1-5$

humile and Italian wall lizard Podarcis sicula. The Italian wall lizard is native to the Italian Peninsula and Sicily but arrived as a hitchhiker on cargo and through the nursery trade on several Mediterranean islands, with similarities to Cyprus, and subsequently established (Silva-Rocha et al. 2014) with documented impacts through competitive exclusion of and hybridisation with native lizards (Nevo et al. 1972; Capula et al. 2002; Downes and Bauwens 2002). The common kingsnake Lampropeltis getula, commonly kept as a pet, established on the Macaronesian islands in the North Atlantic Ocean (Monzón-Argüello et al. 2015). 
This generalist predator could establish on Cyprus and have major adverse effects on native species (including other snakes, turtles, small mammals and birds) (Roy et al. 2018a). Several studies have shown that introduced snakes can have devastating impacts on native (often endemic) herpetofauna of Mediterranean islands, and so impact upon the natural and cultural heritage of island ecosystems, whose inhabitants often consider native species as iconic (Cabrera-Pérez et al. 2012; Silva-Rocha et al. 2018).

Eight of the 20 species predicted to present a very high impact on biodiversity and ecosystems were also considered a threat to human health. It is widely recognised that little is known about the biology of alien pathogens, disease-causing parasites including viruses, bacteria, fungi, protists, and nematodes, and their impacts on after introduction into new regions (Roy et al. 2017). However, we have demonstrated the value of coupling expert opinion with the best available evidence to apply a broad classification of human health impacts within horizon scanning. Here we provide a few examples that demonstrate the value of such an approach in at least making preliminary predictions and highlighting priorities for future research.

Acacia dealbata is an invasive tree species which prefers disturbed habitats, but is also found invading undisturbed plant communities globally (Lazzaro et al. 2014). It reduces biodiversity by competing with native plants, replacing grass communities and increasing water loss from riparian habitats (Lorenzo et al. 2010). Acacia dealbata can also have direct effects on human health through the production of allergenic pollen (Lorenzoni-Chiesura et al. 2000). Furthermore, it has been shown that the increased availability of sugar sources provided by some Acacia species can increase the longevity of female Anopheles sergentii and so enhance their potential to vector malaria (Gu et al. 2011). It has been suggested that local shortages of sugar resources might impede completion of the mosquitos' gonotrophic cycle and reduce vector capacity $(\mathrm{Gu}$ et al. 2011). Malarial transmission is increased 250-fold when additional sugars are available such as from Acacia nectar $(\mathrm{Gu}$ et al. 2011). Therefore, interactions between mosquitoes and invasive Acacia could increase human health risks. A number of species of invasive mosquitoes were considered through our study and, although their impacts on biodiversity are likely to be negligible, the threat they pose to human health is of considerable concern (Martinou and Roy 2018). Therefore, there could be merit in studying whether the establishment of A. dealbata could facilitate the transmission of malaria by providing sugar resources for vectorcompetent mosquito species already present in Cyprus.

Within the marine environment one of the IAS that has impacts upon biodiversity and human health is the striped eel catfish, Plotosus lineatus (Galil 2018). This species has venom glands in its dorsal and pectoral spines and in glandular cells in its skin that secrete a potent toxin (Galil et al. 2017; Galanidi et al. 2018). The injuries it can inflict, particularly on fisheries personnel, can be severe (Gweta et al. 2008). The striped eel catfish is also considered as one of the 100 worst IAS in the Mediterranean on account of both its ecological and human health impacts (Streftaris and Zenetos 2006; Galil 2018).

A number of the IAS predicted to threaten biodiversity and ecosystems are also anticipated to have multiple human health impacts. The Indian house crow Corvus splendens has an obligate association with people and no populations are known to exist independently from humans (Nyári et al. 2006). Invaded areas are mainly urban and semi-urban where the house crows benefit from human food and refuse, although they often nest and roost within nearby farmland and have been shown to reduce bird diversity (Ryall 1992). House crows affect human health as reservoirs of diarrheal diseases and West Nile Virus (Komar et al. 2003) but are also a nuisance to humans. It is intuitive to consider IAS that exert multiple human health impacts as having an increased threat but we did not attempt to rank the categories of human health impact. However, disease vectors such as mosquitoes should perhaps be of greater concern than an IAS considered to cause nuisance such as noise but further work is required to develop approaches for comparing and scoring such human health impacts. The magnitude of health impacts (e.g. prevalence, incidence, morbidity) could be further investigated using specific impact assessment protocols (D'hondt et al. 2015). Also, there is potential to integrate the recently published Socio-Economic Impact Classification for Alien Taxa (SEICAT) (Bacher et al. 2017) within an horizon scanning framework.

The underlying importance of arrival pathways in the invasion process has been well documented (Essl 
et al. 2015). Management of pathways may provide an effective method for preventing the arrival of IAS (McGeoch et al. 2016). The importance of identification, prioritization and management of introduction pathways has also been recognized at policy level as both the CBD and the EU, through the EC Biodiversity Strategy to 2020 and the IAS Regulation, have dedicated targets for combating IAS through management of pathways (Shine et al. 2010; CBD 2014). Therefore, in this study we documented the likely pathways of arrival for the IAS, identified as a potential threat to Cyprus through our horizon scanning approach, using the CBD hierarchical classification system (CBD 2014). It is important to note that the probability of arrival and pathways assigned were within the context of Cyprus including the SBA. Perhaps most notable is the number of pathways that are relevant across all the identified IAS; multiple pathways of arrival are anticipated for many IAS. This presents a challenge with respect to pathway management but it is encouraging that pathways within the escape category dominate, and biosecurity measures could be effective here. However, stowaway is also recognised as a major pathway of arrival; this was also apparent from the GB horizon scanning exercise (Roy et al. 2014a). There are ways to manage and reduce stowaways; through, for example, dedicated biosecurity checks at entry points but naturally, the covert nature of IAS arriving as stowaways presents challenges. Currently, the Republic of Cyprus has established procedures at entry points to ensure official control is in place for intentional introductions of IAS of EU concern and for species that fall under the plant health and animal health legislations. The identification and prioritization of unintentional pathways of IAS from both outside and within the EU, as well as pathways related to non-commercial introductions, are important steps towards the implementation of additional checks and relevant biosecurity measures.

Putting measures in place to tackle introduction pathways requires detailed knowledge of the exact goods and commodities associated with species introductions, for example from interception databases, as well as dedicated surveillance methods. However, the legislative frameworks and agreements in which trade exists should also be taken into account. A lack of interception databases presents a particular challenge to horizon scanning (and also risk assessment and subsequent management). Although logistically difficult to compile, and recognising the need to adhere to recent data privacy requirements embodied within the General Data Protection Regulation, such databases could provide a robust evidence-base for future forecasting through horizon scanning but also underpin evaluation and inform subsequent IAS management. In the absence of data on pathways, such as frequency of species imports, lists and numbers of species kept in captivity and/or sold through the pet trade, there is considerable reliance on the knowledge of experts, particularly ecologists, to predict the movement (and establishment) of potential IAS into new regions. The absence of robust data impairs the ability to apply modelling approaches identifying emerging invasion pathways for stowaway species that are unintentionally transported via goods and services (Tingley et al. 2017).

An interdisciplinary approach to horizon scanning processes, such as the one we have reported here, requires a breadth of expertise from medical and environmental health through to ecology, but the benefits of a collaborative approach are far-reaching. Preliminary lists can be effectively and rapidly agreed by bringing together small interdisciplinary teams and using the methods described here. However, gaps in expertise are inevitably identified through the discussions. It is important to document and assign appropriate confidence levels on the basis of these gaps and to recognise that horizon scanning lists are the first stage in prioritisation of IAS to inform decisionmaking (Roy et al. 2015, 2018a, b). The information gathered through such rapid screening is by necessity less comprehensive than could be achieved through risk assessment (Roy et al. 2018a, b), but horizon scanning provides a short list of species that can be prioritised for full risk assessment. This should be the next step. Additionally, the list can be used to rapidly inform surveillance, monitoring and can guide biosecurity efforts. For example, there are a number of species that could be included within citizen science initiatives with the purpose of both awareness raising and early-warning (Zenetos et al. 2013; Galil et al. 2018). Although it is important to note the difficulties inherent in using citizen science approaches, particularly for early-warning of IAS with low detectability (Pocock et al. 2017), it is encouraging to note a number of successes within the Mediterranean region. In Greece, 28 records were received from the public for marine alien species including the invasive pufferfish, 
Lagocephalus sceleratus (Zenetos et al. 2013). The mapping of the distribution of the lionfish Pterois miles in Cyprus can be partially attributed to citizen scientists (Jimenez et al. 2016; Kletou et al. 2016). In Israel the annual swarming of the venomous jellyfish Rhopilema nomadica has been monitored since the 1990s by a network of swimmers, surfers, lifeguards, yachters, fishermen and others leading to the development of the Mediterranean-wide "JellyWatch" programme (http://www.ciesm.org/marine/programs/ jellywatch.htm) (Galil et al. 2018). Additionally, voluntary sharing through social media of IAS sightings by recreational fishermen has not only provided an up-to-date information on the distribution of channel catfish (Ictalurus punctatus) and European catfish (Silurus glanis) within the invaded range, but also contributed to understanding of the temporal and spatial spread in two Iberian watersheds (Gago et al. 2016; Banha et al. 2017).

It is clear that coordinated and interdisciplinary approaches are key to understanding, detecting and managing the emergence of IAS and their impacts on people and biodiversity at various scales. Robust risk assessments (Roy et al. 2018a, b) are critical for underpinning strategic and legislative decision-making but horizon scanning provides a way to prioritise IAS for this next step, which usually involves a considerable investment of resources. Furthermore, the identification and prioritisation of IAS can be engaging for people and provide a focus for citizen science approaches to monitoring IAS. People are an intimate part of invasion ecology, their actions result in the introduction of IAS, and it is critical that they are part of the solution to reduce the future threat of IAS.

Acknowledgements The authors are grateful to the UK Defra Darwin Initiative Plus for funding this study (reference DarwinPlus056 Assessment of current and future Invasive Alien Species in Cyprus). This work was supported by the Natural Environment Research Council as part of the programmes delivering National Capability. The authors would also like to thank Glen Bullivant and Kevin Shawcoss for their support during this project. FR is supported by FRISK Project (FCT Ref. PTDC/AAG-MAA/0350/2014) and by the strategic plan of MARE (Marine and Environmental Sciences Centre: UID/MAR/04292/2013). The Darwin Initiative project "RIS-Ký" (http://www.ris-ky.eu) includes a focus on developing citizen science approaches for collecting data on alien species on the island of Cyprus. Finally, we thank the anonymous reviewers and editor for the very useful comments they provided.
Open Access This article is distributed under the terms of the Creative Commons Attribution 4.0 International License (http:// creativecommons.org/licenses/by/4.0/), which permits unrestricted use, distribution, and reproduction in any medium, provided you give appropriate credit to the original author(s) and the source, provide a link to the Creative Commons license, and indicate if changes were made.

\section{References}

Arianoutsou M, Delipetrou P, Celesti-Grapow L, Basnou C, Bazos I, Kokkoris Y, Blasi C, Vila M (2010) Comparing naturalised alien plants and recipient habitats across an east-west gradient in the Meditteranean Basin. J Biogeogr 37:1811-1823

Bacher S, Blackburn TM, Essl F, Genovesi P, Heikkilä J, Jeschke JM, Jones G, Keller R, Kenis M, Kueffer C, Martinou AF, Nentwig W, Pergl J, Pyšek P, Rabitsch W, Richardson DM, Roy HE, Saul W-C, Scalera R, Vilà M, Wilson JRU, Kumschick S (2017) Socio-economic impact classification of alien taxa (SEICAT). Methods Ecol Evol 9:159-168

Banha F, Veríssimo A, Ribeiro F, Anastácio PM (2017) Forensic reconstruction of Ictalurus punctatus invasion routes using on-line fishermen records. Knowl Manag Aquat Ecosyst 418:56

Bayliss HR, Schindler S, Adam M, Essl F, Rabitsch W (2017) Evidence for changes in the occurrence, frequency or severity of human health impacts resulting from exposure to alien species in Europe: a systematic map. Environ Evid 6:21

Booy O, Mill AC, Roy HE, Hiley A, Moore N, Robertson P, Baker S, Brazier M, Bue M, Bullock R (2017) Risk management to prioritise the eradication of new and emerging invasive non-native species. Biol Invasions 19:2401-2417

Branquart E (2009) Guidelines for environmental impact assessment and list classification of non-native organisms in Belgium: version 2.6. Belgian Forum on Invasive Species, Bruxelles

Cabrera-Pérez MÁ, Gallo-Barneto R, Esteve I, Patiño-Martínez C, López-Jurado LF (2012) The management and control of the California kingsnake in Gran Canaria (Canary Islands): project LIFE + Lampropeltis. Aliens Invasive Species Bull 32:20-28

Caffrey JM, Baars J-R, Barbour JH, Boets P, Boon P, Davenport K, Dick JT, Early J, Edsman L, Gallagher C (2014) Tackling invasive alien species in Europe: the top 20 issues. Manag Biol Invasions 5:1-20

Capula M, Luiselli L, Bologna MA, Ceccarelli A (2002) The decline of the Aeolian wall lizard, Podarcis raffonei: causes and conservation proposals. Oryx 36:66-72

CBD (2014) Pathways of introduction of invasive species, their prioritization and management. Note by the Executive Secretary. In: 18th Meeting of the subsidiary body on scientific, technical and technological advice (SBSTTA): Montreal, 23-28 June 2014. www.cbd.int/doc/meetings/ sbstta/sbstta-18/official/sbstta-18-09-add1-en.pdf. Viewed 9 Feb 2017 
Christodoulou C (2003) The impact of Acacia saligna invasion on the autochthonous communities of the Akrotiri salt marshes. University of Central Lancashire, Preston

Coll M, Piroddi C, Steenbeek J, Kaschner K, Lasram FBR, Aguzzi J, Ballesteros E, Bianchi CN, Corbera J, Dailianis T (2010) The biodiversity of the Mediterranean Sea: estimates, patterns, and threats. PLoS ONE 5:e11842

D'hondt B, Vanderhoeven S, Roelandt S, Mayer F, Versteirt V, Adriaens T, Ducheyne E, San Martin G, Grégoire J-C, Stiers I (2015) Harmonia $^{+}$and Pandora ${ }^{+}$: risk screening tools for potentially invasive plants, animals and their pathogens. Biol Invasions 17:1869-1883

Delipetrou P, Makhzoumi J, Dimopoulos P, Georghiou K (2008) Cyprus. Mediterranean Island landscapes. Springer, Berlin, pp 170-203

Downes S, Bauwens D (2002) An experimental demonstration of direct behavioural interference in two Mediterranean lacertid lizard species. Anim Behav 63:1037-1046

Essl F, Bacher S, Blackburn TM, Booy O, Brundu G, Brunel S, Cardoso A-C, Eschen R, Gallardo B, Galil B, GarcíaBerthou E, Genovesi P, Groom Q, Harrower C, Hulme P, Katsanevakis S, Kenis M, Kühn I, Kumschick S, Martinou A, Nentwig W, O'Flynn C, Pagad S, Pergl J, Pyšek P, Rabitsch W, Richardson DM, Roques A, Roy HE, Scalera R, Schindler S, Seebens H, Vanderhoeven S, Vilà M, Wilson JRU, Zenetos A, Jeschke JM (2015) Crossing frontiers in tackling pathways of biological invasions. Bioscience 65:769-782

Gago J, Anastácio P, Gkenas C, Banha F, Ribeiro F (2016) Spatial distribution patterns of the non-native European catfish, Silurus glanis, from multiple online sources: a case study for the River Tagus (Iberian Peninsula). Fish Manag Ecol 23:503-509

Galanidi M, Zenetos A, Bacher S (2018) Assessing the socioeconomic impacts of priority marine invasive fishes in the Mediterranean with the newly proposed SEICAT methodology. Mediterr Mar Sci 19:107-123

Galil BS (2018) Poisonous and venomous: marine alien species in the Mediterranean Sea and human health. In: Mazza G, Tricarico E (eds) Invasive species and human health. CABI, Wallingford

Galil B, Marchini A, Occhipinti-Ambrogi A, Ojaveer H (2017) The enlargement of the Suez Canal-Erythraean introductions and management challenges. Manag Biol Invasions 8:141-152

Galil BS, Marchini A, Occhipinti-Ambrogi A (2018) East is east and West is west? Management of marine bioinvasions in the Mediterranean Sea. Estuar Coast Shelf Sci 201:7-16

Gallardo B, Zieritz A, Adriaens T, Bellard C, Boets P, Britton JR, Newman JR, van Valkenburg JLCH, Aldridge DC (2016) Trans-national horizon scanning for invasive nonnative species: a case study in western Europe. Biol Invasions 18:17-30

Georgiades C (1994) The adventive flora of Cyprus, taxonomic, floristic, phytogeographic, ecophysiological study

Gu W, Müller G, Schlein Y, Novak RJ, Beier JC (2011) Natural plant sugar sources of Anopheles mosquitoes strongly impact malaria transmission potential. PLoS ONE 6:e15996

Gucel S, Kadis C, Ozden O, Charalambidou I, Linstead C, Fuller W, Kounnamas C, Ozturk M (2012) Assessment of biodiversity differences between natural and artificial wetlands in Cyprus. Pak J Bot 44:213-224

Gweta S, Spanier E, Bentur Y (2008) Venomous fish injuries along the Israeli Mediterranean coast: scope and characterization. Isr Med Assoc J 10:783

Hadjikyriakou G, Hadjisterkotis E (2002) The adventive plants of Cyprus with new records of invasive species. Z Jagdwiss 48:59-71

Harrower CA, Scalera R, Pagad S, Schonrogge K, Roy HE (2018) Guidance for interpretation of CBD categories on introduction pathways. Report to the European Commission. https://circabc.europa.eu/w/browse/0606f9b8-b5674f53-9bc8-76e7800f0971. Accessed 4 Sept 2018

Havel JE, Kovalenko KE, Thomaz SM, Amalfitano S, Kats LB (2015) Aquatic invasive species: challenges for the future. Hydrobiologia 750:147-170

Hulme PE (2014) Invasive species challenge the global response to emerging diseases. Trends Parasitol 30:267-270

Jeschke JM (2008) Across islands and continents, mammals are more successful invaders than birds. Divers Distrib 14:913-916

Jimenez C, Petrou A, Andreou V, Hadjioannou L, Wolf W, Koutsoloukas N, Alhaija RA, QDivers AN, Aquarium O (2016) Veni, vidi, vici: the successful establishment of the lionfish Pterois miles in Cyprus (Levantine Sea). Rapp Comm Int Mer Mediterr 41:417

Katsanevakis S, Tsiamis K, Ioannou G, Michailidis N, Zenetos A (2009) Inventory of alien marine species of Cyprus. Mediterr Mar Sci 10:109-133

Keller RP, Lodge DM, Finnoff DC (2007) Risk assessment for invasive species produces net bioeconomic benefits. Proc Natl Acad Sci USA 104:203-207

Kletou D, Hall-Spencer JM, Kleitou P (2016) A lionfish (Pterois miles) invasion has begun in the Mediterranean Sea. Mar Biodivers Rec 9:46

Komar N, Langevin S, Hinten S, Nemeth N, Edwards E, Hettler D, Davis B, Bowen R, Bunning M (2003) Experimental infection of North American birds with the New York 1999 strain of West Nile virus. Emerg Infect Dis 9:311

Lazzaro L, Giuliani C, Fabiani A, Agnelli AE, Pastorelli R, Lagomarsino A, Benesperi R, Calamassi R, Foggi B (2014) Soil and plant changing after invasion: the case of Acacia dealbata in a Mediterranean ecosystem. Sci Total Environ 497:491-498

Lorenzo P, González L, Reigosa MJ (2010) The genus Acacia as invader: the characteristic case of Acacia dealbata Link in Europe. Ann For Sci 67:101

Lorenzoni-Chiesura F, Giorato M, Marcer G (2000) Allergy to pollen of urban cultivated plants. Aerobiologia 16:313-316

Martinou AF, Roy HE (2018) From local strategy to global frameworks: effects of invasive non-native species on health and well-being. In: Mazza L, Tricarico E (eds) Invasive species and human health. CABI, Wallingford

McGeoch MA, Genovesi P, Bellingham PJ, Costello MJ, McGrannachan C, Sheppard A (2016) Prioritizing species, pathways, and sites to achieve conservation targets for biological invasion. Biol Invasions 18:299-314

Monzón-Argüello C, Patiño-Martínez C, Christiansen F, GalloBarneto R, Cabrera-Pérez MÁ, Peña-Estévez MÁ, LópezJurado LF, Lee PL (2015) Snakes on an island: independent 
introductions have different potentials for invasion. Conserv Genet 16:1225-1241

Myers PG, Haines K (2000) Seasonal and interannual variability in a model of the Mediterranean under derived flux forcing. J Phys Oceanogr 30:1069-1082

Myers N, Mittermeier RA, Mittermeier CG, Da Fonseca GA, Kent J (2000) Biodiversity hotspots for conservation priorities. Nature 403:853

Nevo E, Gorman G, Soulé M, Yang SY, Clover R, Jovanović V (1972) Competitive exclusion between insular Lacerta species (Sauria, Lacertidae). Oecologia 10:183-190

Nyári A, Ryall C, Townsend Peterson A (2006) Global invasive potential of the house crow Corvus splendens based on ecological niche modelling. J Avian Biol 37:306-311

Pocock MJ, Roy HE, Fox R, Ellis WN, Botham M (2017) Citizen science and invasive alien species: predicting the detection of the oak processionary moth Thaumetopoea processionea by moth recorders. Biol Conserv 208:146-154

Roy HE, Peyton J, Aldridge DC, Bantock T, Blackburn TM, Britton R, Clark P, Cook E, Dehnen-Schmutz K, Dines T, Dobson M, Edwards F, Harrower C, Harvey MC, Minchin D, Noble DG, Parrott D, Pocock MJO, Preston CD, Roy S, Salisbury A, Schönrogge K, Sewell J, Shaw RH, Stebbing P, Stewart AJA, Walker KJ (2014a) Horizon scanning for invasive alien species with the potential to threaten biodiversity in Great Britain. Glob Change Biol 20:3859-3871

Roy HE, Schonrogge K, Dean H, Peyton J, Branquart E, Vanderhoeven S, Copp G, Stebbing P, Kenis M, Rabitsch W, Essl F, Schindler S, Brunel S, Kettunen M, Mazza L, Nieto A, Kemp J, Genovesi P, Scalera R, Stewart A (2014b) Invasive alien species: framework for the identification of invasive alien species of EU concern (ENV.B.2/ETU/ 2013/0026). European Commission, Brussels

Roy HE, Adriaens T, Aldridge DC, Bacher S, Bishop JDD, Blackburn TM, Branquart E, Brodie J, Carboneras C, Cook EJ, Copp GH, Dean HJ, Eilenberg J, Essl F, Gallardo B, Garcia M, García-Berthou E, Genovesi P, Hulme PE, Kenis M, Kerckhof F, Kettunen M, Minchin D, Nentwig W, Nieto A, Pergl J, Pescott O, Peyton J, Preda C, Rabitsch W, Roques A, Rorke S, Scalera R, Schindler S, Schönrogge K, Sewell J, Solarz W, Stewart A, Tricarico E, Vanderhoeven S, van der Velde G, Vilà M, Wood CA, Zenetos A (2015) Invasive alien species: prioritising prevention efforts through horizon scanning ENV.B.2/ETU/2014/0016. European Commission

Roy HE, Hesketh H, Purse BV, Eilenberg J, Santini A, Scalera R, Stentiford GD, Adriaens T, Bacela-Spychalska K, Bass D (2017) Alien pathogens on the horizon: opportunities for predicting their threat to wildlife. Conserv Lett 10:477-484

Roy HE, Rabitsch W, Scalera R (2018a) Study on invasive alien species: development of risk assessments to tackle priority species and enhance prevention. Final report for the European Commission. Contract no 07.0202/2016/ 740982/ETU/ENV.D2

Roy HE, Rabitsch W, Scalera R, Stewart A, Gallardo B, Genovesi P, Essl F, Adriaens T, Bacher S, Booy O (2018b) Developing a framework of minimum standards for the risk assessment of alien species. J Appl Ecol 55:526-538

Roy HE, Bacher S, Essl F, Adriaens T, Aldridge DC, Bishop JDD, Blackburn TM, Branquart E, Brodie J, Carboneras C,
Cottier-Cook EJ, Copp GH, Dean HJ, Eilenberg J, Gallardo B, Garcia M, García-Berthou E, Genovesi P, Hulme PE, Kenis M, Kerckhof F, Kettunen M, Minchin D, Nentwig W, Nieto A, Pergl J, Pescott OL, Peyton JM, Preda C, Roques A, Rorke SL, Scalera R, Schindler S, Schönrogge K, Sewell J, Solarz W, Stewart AJA, Tricarico E, Vanderhoeven $\mathrm{S}$, van der Velde $\mathrm{G}$, Vilà $\mathrm{M}$, Wood CA, Zenetos A, Rabitsch W (2019) Developing a list of invasive alien species likely to threaten biodiversity and ecosystems in the European Union. Global Chang Biol 25:1032-1048

Russell JC, Meyer J-Y, Holmes ND, Pagad S (2017) Invasive alien species on islands: impacts, distribution, interactions and management. Environ Conserv 44:359-370

Ryall C (1992) Predation and harassment of native bird species by the Indian house crow, Corvus splendens, in Mombasa, Kenya. Scopus 16:1-8

Schindler S, Staska B, Adam M, Rabitsch W, Essl F (2015) Alien species and public health impacts in Europe: a literature review. NeoBiota 27:1

Seebens H, Blackburn TM, Dyer EE, Genovesi P, Hulme PE, Jeschke JM, Pagad S, Pyšek P, Winter M, Arianoutsou M, Bacher S, Blasius B, Brundu G, Capinha C, Celesti-Grapow L, Dawson W, Dullinger S, Fuentes N, Jäger H, Kartesz J, Kenis M, Kreft H, Kühn I, Lenzner B, Liebhold A, Mosena A, Moser D, Nishino M, Pearman D, Pergl J, Rabitsch W, Rojas-Sandoval J, Roques A, Rorke S, Rossinelli S, Roy HE, Scalera R, Schindler S, Štajerová K, Tokarska-Guzik B, van Kleunen M, Walker K, Weigelt P, Yamanaka T, Essl F (2017) No saturation in the accumulation of alien species worldwide. Nat Commun 8:14435

Shine C, Kettunen M, Genovesi P, Essl F, Gollasch S, Rabitsch W, Scalera R, Starfinger U, ten Brink P (2010) Assessment to support continued development of the EU Strategy to combat invasive alien species. Final report for the European Commission. Institute for European Environmental Policy (IEEP), Brussels

Silva-Rocha I, Salvi D, Harris DJ, Freitas S, Davis C, Foster J, Deichsel G, Adamopoulou C, Carretero MA (2014) Molecular assessment of Podarcis sicula populations in Britain, Greece and Turkey reinforces a multiple-origin invasion pattern in this species. Acta Herpetol 9:253-258

Silva-Rocha I, Montes E, Salvi D, Sillero S, Mateo JA, Ayllón E, Pleguezuelos JM, Carretero MA (2018) Herpetological history of the Balearic Islands: when aliens conquered these islands and what to do next. Histories of bioinvasions in the Mediterranean. Springer, Berlin, pp 105-131

Simberloff D (1995) Why do introduced species appear to devastate islands more than mainland areas. Pac Sci 49:87-97

Sparrow D, John E (2016) An introduction to the wildlife of Cyprus. Terra Cypria, Limassol

Streftaris N, Zenetos A (2006) Alien marine species in the Mediterranean-the 100 'Worst Invasives' and their impact. Mediterr Mar Sci 7:87-118

Streftaris N, Zenetos A (2009) Evidence of climate change on Greek marine and coastal biodiversity. In: Proceedings 9th symposium on oceanography \& fisheries, pp 675-680

Tingley R, García-Díaz P, Arantes CRR, Cassey P (2017) Integrating transport pressure data and species distribution models to estimate invasion risk for alien stowaways. Ecography 41:635-646 
Tricarico E, Junqueira AO, Dudgeon D (2016) Alien species in aquatic environments: a selective comparison of coastal and inland waters in tropical and temperate latitudes. Aquat Conserv Mar Freshw Ecosyst 26:872-891

Tsiamis K, Zenetos A, Deriu I, Gervasini E, Cardoso AC (2018) The native distribution range of the European marine nonindigenous species. Aquat Invasions 13:187-198

Tsintides T, Christodoulou CS, Delipetrou P, Georghiou K (2007) The red data book of the flora of Cyprus. Cyprus For Assoc, Lefkosia, p 465

Vanderhoeven S, Adriaens T, D'hondt B, Van Gossum H, Vandegehuchte M, Verreycken H, Cigar J, Branquart E (2015) A science-based approach to tackle invasive alien species in Belgium - the role of the ISEIA protocol and the Harmonia information system as decision support tools. Manag Biol Invasions 6:197-208

Vilà M, Hulme PE (2017) Non-native species, ecosystem services, and human well-being. Impact of biological invasions on ecosystem services. Springer, Cham, pp 1-14

Ward D, Stanley M, Toft R, Forgie S, Harris R (2008) Assessing the risk of invasive ants: a simple and flexible scorecard approach. Insectes Soc 55:360-363
Zenetos A, Vassilopoulou V, Salomidi M, Poursanidis D (2008) Additions to the marine alien fauna of Greek waters (2007 update). Mar Biodivers Rec 1:E91. https://doi.org/10.1017/ S1755267207009281

Zenetos A, Katsanevakis S, Poursanidis D, Crocetta F, Damalas D, Apostolopoulos G, Gravili C, Vardala-Theodorou E, Malaquias M (2011) Marine alien species in Greek Seas: additions and amendments by 2010. Mediterr Mar Sci 12(1):95-120

Zenetos A, Koutsogiannopoulos D, Ovalis P, Poursanidis D (2013) The role played by citizen scientists in monitoring marine alien species in Greece. Cah Biol Mar 54:419-426

Zenetos A, Çinar ME, Crocetta F, Golani D, Rosso A, Servello G, Shenkar N, Turon X, Verlaque M (2017) Uncertainties and validation of alien species catalogues: the Mediterranean as an example. Estuar Coast Shelf Sci 191:171-187

Publisher's Note Springer Nature remains neutral with regard to jurisdictional claims in published maps and institutional affiliations. 